\title{
Predicting the bear currency carry trade market: does it add economic value?
}

\section{Laborda, Ricardo}

Laborda, Juan

- ReCeived: 14 September 2013

- accepted: 24 january 2014

\begin{abstract}
The failure of the uncovered interest rate parity implies that currency carry trading delivers positive predictable excess returns on average. However, currency carry trading exhibits long periods of steady gains and sudden periods of high volatility with reversals in previous gains. We analyse the predictability of bear and bull currency carry trade markets using financial variables as leading indicators. We find that the US TED spread, the three-month $C R B$ Industrial return, the currency carry trade factor and the $F X$ volatility have out-of-sample predictive power for the bear currency carry trade market probability, which also provides valuable portfolio signals to investors.
\end{abstract}

\section{Keywords:}

Bear currency carry trade markets, Turning point, Markov switching model, Probit model, Optimal investor portfolio, Out-of-sample forecasts.

JEL classification:

C52, C53, F31, G11, G15.

Laborda, R., Centro Universitario de la Defensa,Academia General Militar. Ctra Huesca s/n 50090, Zaragoza, Spain. Email: rlaborda@unizar.es.

Laborda, J., Instituto de Estudios Bursátiles (IEB), Calle Alfonso XI 280 I4, Madrid, Spain, and Universidad Carlos III de Madrid (UC3M), Av. de la Universidad, 30, 289I I, Madrid, Spain.Email:juan.labordah@gmail.com. 


\title{
La predicción del mercado bajista del carry trade de divisas: iproporciona valor al inversor?
}

\author{
Laborda, Ricardo \\ Laborda, Juan
}

\section{Resumen}

El rechazo de la teoría de la paridad descubierta de los tipos de interés implica que la estrategia de carry trade de divisas proporciona rendimientos predecibles en exceso y positivos en promedio. Sin embargo, la estrategia de carry trade de divisas alterna largos periodos de ganancias estables con repentinos periodos de elevada volatilidad que revierten las ganancias previas. Analizamos la capacidad de predicción del mercado bajista del carry trade de divisas utilizando variables financieras como indicadores adelantados. Nuestros resultados muestran que el US TED spread, la variación tres meses del $C R B$ Industrial, un factor de carry y la volatilidad del mercado de divisas tienen capacidad predictiva de la probabilidad del mercado bajista de carry de divisas, lo que también proporciona valiosas recomendaciones de cartera.

\section{Palabras clave:}

Periodo bajista del mercado de carry trade de divisas, puntos de giro, modelo Markov Switching, modelo Probit, formación de cartera óptima, predicciones fuera de la muestra. 


\section{Introduction}

One of the more popular strategies implemented in the FX market is currency carry trading, which consists of selling low interest rate currencies, "funding currencies", and investing the proceeds in high interest rate currencies, "investment currencies". The uncovered interest rate parity (UIP) condition predicts that rational investors should expect that the carry gain resulting from the risk-free interest rate differential between countries will be offset by an expected depreciation in the high yield currencies. Hence, an investor who engages in the usual currency carry trade should expect a zero net payoff. In a seminal paper, Fama (1984) noted that in practice the reverse holds, that is, high interest rate currencies tend to appreciate against low interest rate currencies, suggesting that the forward premium, defined as the difference between the forward and spot currency prices, tends to be related inversely to future exchange rate changes. This empirical phenomenon is the wellknown "forward bias puzzle" that rejects the efficiency of the foreign exchange market by considering that the currency excess returns time series exhibits predictability and also, most importantly, it suggests the existence of profitable strategies, currency carry trades, obtained from selling and buying currencies based on forward discounts (Bakshi and Panayotov, 2013). With the failure of the UIP, an investor would expect positive predictable excess returns for investments in high interest rate currencies and negative predictable excess returns for investments in low interest rate currencies.

However, this strategy is subject to crash risk in periods of increasing risk aversion and liquidity squeezing, producing the reversal of currency values between high and low interest rate countries (Brunnermeier et al., 2008). Hence, the predictable excess returns of currency carry trading cannot be interpreted as a risk-free arbitrage strategy and can be explained rationally as the compensation demanded by the investor for bearing some economic risks (Lustig and Verdelhan, 2007; Lustig et al., 2013).

The currency carry trade strategy exhibits long periods of steady gains and sudden periods of high volatility with reversals in previous gains. This behaviour matches the usual definition of bear and bull markets and also has a clear impact on the optimal investor portfolio decision. If investors were able to anticipate the periods of declining (rising) currency carry trade values, or equivalently the bear (bull) currency carry trade market, they would go long (short) in low interest rate currencies and go short (long) in high interest rate currencies.

The aim of this paper is twofold. First, we want to examine the bear currency carry trade market using the information from financial variables as leading indicators. To do so, we characterize the bear currency carry trade market using parametric and 
non-parametric approaches that have been considered to describe bear stock markets (Chen, 2009). In particular, we employ Markov switching models and Bry and Boschan's (1971) dating method to describe fluctuations in the currency carry trade market. After identifying the bear currency carry trade market periods, we evaluate if these periods can be predicted for in-sample and out-of-sample observations using financial variables given different time horizons. In doing so, we can obtain for each financial variable and time horizon the corresponding bear currency carry trade market probability forecast.

Second, we evaluate the economic value of the one-month bear currency carry trade market probability forecast within an asset allocation context. We assume an optimal asset allocation setting that is defined by the maximization of the expected utility function of an investor, conditional on the information set characterized by the onemonth bear currency carry trade market probability forecast. This probability is used to generate directly the optimal currency carry trade bet size, following recent literature which tries to draw inferences about the optimal investor portfolio choice directly from the data without modelling returns (see Ait-Sahalia and Brandt, 2001; Barroso and Santa-Clara, 2012; Brandt, 1999; Brandt et al., 2009). We assume that the optimal currency carry trade bet size depends linearly on the bear currency carry trade market probability forecast and employ a $C R R A$ utility function to model investors' risk aversion profiles. Our portfolio decision avoids the use of a priori values of the bear currency carry trade market probability in order to determine the optimal portfolio decision (Chen, 2009). We also rule out the traditional asset allocation procedure. This approach consists of drawing inferences about the financial asset returns, which are used to derive the optimal portfolio decision. In doing so, we mitigate the effect of the risk of severe return model misspecification and estimation error that is accentuated in the optimization process.

Using the naïve currency carry trade strategy as a benchmark, we consider the following metrics to evaluate the economic value of the optimal investor decision: 1 ) the Sharpe ratio, 2) the terminal wealth and 3) the annualized difference between the certainty equivalent returns.

Our empirical results are obtained for a sample of monthly data spanning the period 1990 to 2013 and hence covering the recent turmoil in financial markets. The currencies included in the currency carry trade strategy are quoted against the US dollar and comprise the currencies of the G10 group of developed economies: Australia, Canada, Switzerland, Germany, the United Kingdom, Japan, Norway, New Zealand, Sweden and the United States. To study the naïve currency carry trade benchmark, we use the "FXFB Crncy" strategy reported by Bloomberg, which shows the returns of the currency carry trade strategy based on G10 currencies that goes 
long in the three highest yield currencies and short in the three lowest yield currencies.

Our results reveal that the US TED spread, the three-month $C R B$ Industrial return, the $F X$ volatility and the currency carry factor have in-sample and out-of-sample predictive power of future bear currency carry trade probability, also providing remarkable economic value to the investor. The investors who consider the onemonth bear currency carry trade probability forecast from these models obtain gains, compared to the naïve currency carry trade, in terms of the Sharpe ratio, the terminal wealth and the certainty equivalent obtained. As expected, we find that the optimal currency carry trade bet size depends negatively on the one-month bear currency carry trade market probability forecast.

The rest of the paper is structured as follows: Section 2 outlines the econometric background employed in this paper to predict the bear currency carry trade market. Section 3 describes the data and the financial variables used to predict the bear currency carry trade market probability, as well as the predictive power of the models and financial variables examined. Section 4 presents the investor's optimal asset allocation problem and the economic value of the bear currency carry trade probability forecast for an investor who seeks to time currency carry trade market fluctuations. Section 5 concludes.

\section{Econometric framework}

This section describes the definition of the currency excess returns that are used to characterize the performance of the currency carry trade strategy considered in this paper. To characterize the bear currency carry trade market, we also present the parametric and non-parametric models proposed. Finally, we discuss the models used to evaluate the in-sample and out-of-sample predictive power of the financial variables that could potentially anticipate the bear currency carry trade markets.

\subsection{Currency carry trade returns}

Let us consider the case of a US investor who wishes to invest in some foreign currency. This individual could borrow US dollars at the domestic risk-free interest rate $\left(r f_{t}^{U S}\right)$ and buy the foreign currency at a price $1 / S_{t}^{i}$ (where $S_{t}^{i}$ is defined as units of USD per foreign currency unit). The investor could invest at the foreign interest rate $r f_{t}^{i}$ and convert into US dollars at the end of the period for $S_{t+1}^{i}$. The dollar-denominated payoff $\left(R_{t+1}^{i}\right)$ on this strategy without considering transaction costs is:

$$
R_{t+1}^{i}=\frac{S_{t+1}^{i}}{S_{t}^{i}}\left(1+r f_{t}^{i}\right)-\left(1+r f_{t}^{U S}\right)
$$


Taking logs, and using a logarithmic approximation, we have:

$$
r_{t+1}^{i}=s_{t+1}^{i}-s_{t}^{i}-\left(r f_{t}^{U S}-r f_{t}^{i}\right),
$$

where $r_{t+1}^{i}$ and $s_{t}^{i}$ are the logs of $R_{t+1}^{i}$ and $S_{t}^{i}$.

Alternatively, the investor could rely on the forward market by committing to buy for $F_{t, t+1}$ the foreign currency forward for a transaction agreed on time $t$ to take place at time $t+1$. So, $F_{t, t+1}$ is the forward price of the foreign currency at time $t$ with delivery at time $t+1$. Under the absence of arbitrage, it follows that $F_{t, t+1}^{i}=\frac{S_{t}^{i}\left(1+r f_{t}^{U S}\right)}{\left(1+r f_{t}^{i}\right)}$, so that the covered interest rate parity condition is fulfilled. At time $t+1$ the investor liquidates the position, selling the currency for $S_{t+1}^{i}$. The dollar-denominated payoff from this strategy is:

$$
R_{t+1}^{i}=\frac{S_{t+1}^{i}}{F_{t, t+1}^{i}}-1=\frac{S_{t+1}^{i}\left(1+r f_{t}^{i}\right)}{S_{t}^{i}\left(1+r f_{t}^{U S}\right)}-1,
$$

and taking logs, we again obtain (2).

The UIP implies that the expected foreign exchange gain must be offset by the opportunity cost of holding funds in this currency rather than in another, the interest rate differential, and the expected currency excess return should be zero. However, the empirical evidence against the UIP discussed earlier motivates investors to engage in the so-called currency carry trade strategies consisting of selling the foreign currency forward when it is at a forward premium $\left(F_{t, t+1}^{i}>S_{t}^{i}\right)$ and buying the foreign currency forward when it is at a forward discount $\left(F_{t, t+1}^{i}<S_{t}^{i}\right)$.

We consider the naïve currency carry trade portfolio that consists of a long position on the three highest yield currencies and a short position on the three lowest yield currencies from a basket of the G10 currencies, delivering a payoff $R_{t+1, \text { Carry }}$. This portfolio is rebalanced monthly and implemented through the use of currency forwards implying, in turn, the possibility of highly leveraged positions. Clearly, the naïve currency carry trade portfolio is a zero-investment portfolio that does not require initial investment as it consists of positions in the forward markets only. The choice of this portfolio is motivated by its availability; the Bloomberg "FXFB Crncy" function reports the profitability of this portfolio.

\subsection{Identifying currency carry trade fluctuations}

We examine the bear currency carry trade market using parametric and nonparametric methods considered in the literature in relation to the prediction of bear and bull stock markets (Chen, 2009), which allow us to characterize the fluctuations 
in the currency carry trade market. In doing so, we identify the prolonged periods of decreases and increases in values of the currency carry trade market.

\subsubsection{Parametric approach: Markov switching model}

The parametric dating method is based on the Markov switching model introduced by Hamilton (1989) to analyse the dynamics of US real GNP growth, which is characterized by expansion and recession periods around a long-term trend. The abrupt changes in the behaviour of financial markets motivate the use of the Markov switching model to characterize the dynamics of asset prices. Regime switching models can capture sudden changes that can be transitory or more persistent, as well as the stylized behaviour of financial asset returns such as negative skewness, fat tails and volatility clustering (Ang and Timmermann, 2011). Currency carry trade movements also exhibit long periods of steady gains and sudden periods of high volatility with reversals in previous gains. Therefore, currency carry trade payoffs are highly skewed and display excess kurtosis (Burnside, 2012). This behaviour of "going up by the stairs and down by the elevator" (Brunnermeier et al., 2008) justifies the consideration of Markov switching models to explain currency carry trade dynamics.

Let $R_{t, \text { carry }}=\Delta P_{t}$ as the logarithmic change of the currency carry trade value, $P_{t}$. Let $s_{t}=i(i=0,1)$ denote the two states, the bear currency carry trade market $\left(s_{t}=1\right)$ or bull currency carry trade market $\left(s_{t}=0\right)$. We estimate a simple two-state mean/variance model of currency carry trade returns:

$$
R_{t, c a r r y}=\mu_{s_{t}}+\varepsilon_{t}, \quad \varepsilon_{t} \text {-i.i.d. } N\left(0, \sigma_{s_{t}}^{2}\right),
$$

where the mean, $\mu_{s_{t}}$, and variance, $\sigma_{s_{t}}^{2}$, are state dependent. The state variable is assumed to follow a first order Markov chain process with fixed transition probabilities, $p_{i j}$, given by:

$$
P\left\{s_{t}=j \mid s_{t-1}=i\right\}=p_{i j} \quad \forall i, j=0,1 .
$$

The parameters and the probabilities are estimated via maximum likelihood. For the analysis here, we consider filtered probabilities that include information up to time $t$. Thus, $P\left\{s_{t}=1 \mid R_{t, \text { carry }}\right\}$ is the bear currency carry trade market Markov switching estimate.

\subsubsection{Non-Parametric approach: Bry-Boschan Algorithm}

The definition of bear and bull currency carry trade markets as periods of prolonged expanding and contracting values resulting from a strategy that goes long in high yield currencies and short in low yield currencies can be done using the Bry-Boschan (1971) algorithm. Following Candelon et al. (2008), we do not smooth the currency carry 
trade time series and use a six-month estimation window to characterize the peaks and troughs. Once the turning points are obtained for the bear (bull) currency carry trade market, the peaks-to-troughs (troughs-to-peaks) are marked as bear $D_{t}=1$ (bull $D_{t}=0$ ) currency carry trade markets. Thus, $D_{t}$ is a dummy variable.

\subsection{Models to predict the currency carry trade bear market}

Once the bear periods are defined, we set up the econometric models used to predict them. We also discuss the in-sample and out-of-sample tests of the models used to predict the bear currency carry trade markets to assess the predictive power of the explanatory financial variables considered in this paper (see Chen, 2009).

\subsubsection{Linear predictive regressions}

We use simple linear regression models to predict the filtered probability of the bear currency carry trade market, $P\left\{s_{t}=1 \mid R_{t, c a r r y}\right\}$, estimated by the Markov switching model, using financial variables, $x_{t}$, that are expected to be related to the currency carry trade return distribution. The econometric specification is:

$$
P_{1, t+k}\left\{s_{t}=1 \mid R_{t, c a r r y}\right\}=\alpha+\beta x_{t}+v_{t+k} \quad \forall v_{t+k} \sim N\left(0, \sigma^{2}\right) .
$$

We measure the predictive ability at different horizons ( $k=1,3,6,12,24$ months).

To evaluate the in-sample predictive power of the explanatory variables, we employ the traditional $t$-test to test the parameter significance and the goodness of fit of the model, measured by $R^{2}$.

To evaluate the out-of-the sample performance of the linear model, we use the Clark and West (2007) test. This test is used to compare a parsimonious null model to a larger model that nests the null model, adjusting the mean squared prediction errors to account for the noise introduced by the larger model when estimating parameters the population values of which are zero. We can consider the following nested models:

$$
\begin{aligned}
& \text { Restricted model: } P_{1, t+k}\left\{s_{t}=1 \mid R_{t, \text { carry }}\right\}=\alpha+e_{\text {restricted }, t+k} . \\
& \text { Unrestricted model: } P_{1, t+k}\left\{s_{t}=1 \mid R_{t, \text { carry }}\right\}=\alpha+\beta x_{t}+e_{\text {unrestricted }, t+k} .
\end{aligned}
$$

We divide the total sample ( $T$ ) into two portions, in-sample $Q$ and out-of-sample $R$. We use a recursive scheme to make the predictions, using all the information available up to the time the forecast is made. Let $\hat{P}_{1, t+k}^{\text {restricted }}$ and $\hat{P}_{1, t+k}^{\text {unrestricted }}$ denote the $k$-step ahead forecasts from models (7) and (8) with corresponding forecast errors $\hat{e}_{\text {restricted }, t+k}$ and 
$\hat{e}_{\text {unrestricted }, t+k}$. Let $\hat{f}_{t+k}=\hat{e}_{\text {restricted }, t+k}^{2}-\left[\hat{e}_{\text {unrestricted }, t+k}^{2}-\left(\hat{P}_{1, t+k}^{\text {restricted }}-\hat{P}_{1, t+k}^{\text {unrestricted }}\right)^{2}\right]$ be the adjusted mean squared prediction error with the corresponding sample mean $\bar{f}=R^{-1} \sum_{t=R}^{t} \hat{f}_{t+k}$. We test for equal adjusted mean squared prediction errors by regressing $\hat{f}_{t+k}$ on a constant and using the resulting $t$-statistic as a zero coefficient. A significantly positive $t$-statistic implies the higher predictive power of the unrestricted model. The critical values are 1.282 (10\%) and 1.645 (5\%) (Clark and West, 2007).

\subsubsection{Binary choice models}

The binary time series defined in 2.2.b takes the value one $\left(D_{t}=1\right)$ if the currency carry trade market is characterized as a bear market and zero $\left(D_{t}=0\right)$ during bull currency carry trade markets. In this study, we apply static binary models to forecast the bear markets using the financial variables $x_{t}$. We estimate the following probit model:

$$
P\left\{D_{t+k}=1\right\}=F\left(\alpha+\beta x_{t}\right) .
$$

The in-sample predictive model performance is evaluated by the values of the pseudo$R^{2}$ (Estrella, 1998). Let $L_{\text {unrestricted }}$ denote the value of the maximized likelihood and let $L_{\text {restricted }}$ denote the value of the maximized likelihood under the constraint that all the coefficients are zero except for the constant. The measure of fit is:

$$
\text { Pseudo- } R^{2}=\text { Pseudo- } R^{2}=1-\left(\frac{L_{\text {unrestricted }}}{L_{\text {restricted }}}\right)^{-\left(\frac{2}{T}\right) \log \left(L_{\text {restriceded }}\right)} \text {. }
$$

A low (high) value of the pseudo- $R^{2}$ suggests low (high) predictive power of the explanatory variable. If the pseudo- $R^{2}=1$, the model is "perfect".

To evaluate the out-of-the sample performance of the probit model, we consider the quadratic probability score (QPS) proposed by Diebold and Rudebusch (1989):

$$
Q P S=T^{-1} \sum_{t} 2\left[P\left(D_{t+k}=1\right)-D_{t+k}\right]^{2}
$$

This statistic ranges from 0 to 2 , with a score of 0 corresponding to perfect model accuracy.

\section{Data and empirical results:} predicting bear currency carry trade markets

In this section, we discuss the choice of the financial variables used to predict bear currency carry markets and describe the dataset used in our empirical analysis. We also present the in-sample and out-of-sample predictive power of each financial 
variable and linear and probit models used to explain the bear currency carry market probability, which is estimated using parametric and non-parametric models.

\subsection{Currency carry trade cycles and predictive variables}

This section discusses the choice of the financial variables used to predict bear currency carry trade markets. We follow the literature that attempts to determine factors with the potential to explain the failure of UIP, giving rise to the question of the predictability of excess currency returns. Interestingly, the traditional factor models ( $C A P M$, the Fama-French three-factor model and the CCAPM) used to explain stock and bond market returns fail to explain the returns on carry trade (Burnside, 2012). Hence, the literature has focused on the study of the specific risk factors that could price currency returns.

Lustig et al. (2013) show that excess currency returns are highly predictable and counter-cyclical, increasing in downturns and decreasing in expansions as in the case of stock markets and bond returns, supporting the view that these returns are compensation for bearing macroeconomic risk. They find that the average forward discount $(A F D)$ of the US dollar against developed market currencies is the best predictor of average foreign currency excess returns earned by US investors holding a long position in a large basket of foreign currencies and a short position in the US dollar. Lustig et al. (2011) build monthly portfolios of currencies sorted by their forward discounts against the US dollar and identify two common risk factors that most of the time explain variation in currency returns: (1) the dollar risk factor, $R X$, that is the average excess returns of portfolios, and (2) the return on a zerocost strategy that goes long in the highest and short in the lowest interest rate currencies, called $H M L_{F X}$, which proxies the carry trade premium dependent on the global price of risk. It is worth noting that $H M L_{F X}$ is a statistical currency factor risk that is constructed in a spirit similar to the three-factor model proposed by Fama and French (1993) to explain expected stock returns.

Some authors also study the relation between the currency carry trade returns and crash risk. Negative skewness in currency carry trades is due to the sudden unwinding of carry trade positions, which tend to occur when funding liquidity and risk appetite diminish, thus increasing the price of crash risk. Rafferty (2011) use a factor analogous to the $H M L_{F X}$ that measures global currency skewness. This factor sorts currencies into two groups, one with positive forward discounts and another with negative forward discounts. The average of the realized skewness of the currencies in the first group and the negative skewness of the currencies in the second group is the global currency skewness factor. More negative global currency skewness is associated with a greater tendency of high interest rate investment currencies to depreciate 
relative to low interest rate funding currencies, leading to currency carry trade losses. Therefore, the low interest rate currencies provide a hedge against currency carry crashes and high interest rates are most exposed to them.

Financial distress affects funding constraints through the redemption of capital by speculators, losses and margins. Measures of global risk aversion, such as the $V I X$ index, and money market liquidity, such as the TED spread, are found to be positively correlated to currency crashes and future currency returns. Christiansen et al. (2010) also find that the risk exposure of carry trade returns based on G10 currencies is highly dependent on $F X$ volatility and funding liquidity. Menkhoff et al. (2012) consider a factor that measures global currency volatility constructed on a monthly basis, which is the average intra-month realized volatility of the daily log changes in the value of each currency against the US dollar, to explain a crosssection of currency portfolio returns. They find a negative return co-movement for high interest rate currencies with innovations in $F X$ volatility, whereas low interest rate currencies provide a hedge against volatility shocks.

Another important determinant of real exchange rate movements is the evolution of commodity prices in countries where primary commodities constitute a significant share of their exports, as in Canada, New Zealand and Australia (Chen and Rogoff, 2003), which have a positive commodity price elasticity with real exchange rates. These countries are usually linked to "high interest rate currencies". Bakshi and Panayotov (2013) also find that the three-month CRB Industrial return is positively related to future currency carry trade returns.

Following the above literature, we choose the following state variables to predict bear currency carry trade markets: (1) the three-month US AFD, related to the US dollar risk premium and future negative skewness of the currency carry trade return distribution; (2) the currency carry trade return itself, or the currency carry trade factor, which should be linked to global risk and momentum effects on currency markets; (3) the global currency skewness factor; (4) the VIX index; (5) the US TED spread, measured as the difference between the three-month US LIBOR interbank market interest rate and the three-month US Treasury bill rate; (6) the three-month CRB Industrial return; 7) the FX volatility.

\subsection{Data description}

The sample covers the period January 1990 to October 2013. Data are collected from Bloomberg on a monthly basis for the three-month US Treasury bill rate and the G10 three-month interbank interest rate used to create the average US forward discount and the US TED spread; we also collect monthly observations for the VIX 
index and the $C R B$ Industrial return, as well as daily observations for the G10 currency exchange rates used to construct the $F X$ volatility factor, that is the average sample standard deviation of the daily log changes in the values of the currencies against the US dollar.

To study the naïve currency carry trade benchmark, we employ the "FXFB Crncy" strategy reported by Bloomberg, which shows the returns of the currency carry trade strategy that goes long in the three highest yield G10 currencies and short in the three lowest yield currencies. The average annualized carry trade return is $5.74 \%$ and the volatility is $9.18 \%$. The distribution of the carry trade strategy is left skewed and left tailed; the maximum drawdown reaches $31.78 \%$, which provides evidence of the downside risk implied by the usual currency carry trade strategy. We also collect daily data for the currency carry trade to proxy the global currency skewness factor. To construct our measure of the global currency skewness factor on a monthly basis, we take the intra-month realized skewness of the daily return on the currency carry trade strategy.

\subsection{Predicting bear currency carry trade markets: empirical results}

This section presents the in-sample and out-of-sample predictive power of the financial variables and models to predict the bear currency carry trade market estimated using Markov switching models and the Bry-Boschan (1971) algorithm.

\subsubsection{In-sample results}

Table 1 presents the estimation results of the linear and the Markov switching model. The estimation of parameters allows us to identify two regimes in the currency carry trade returns. ${ }^{1}$ As expected, the bear currency carry trade market is characterized by a negative monthly return $(-0.81 \%)$ and high volatility $(2.37 \%)$. The bull currency carry trade market is associated with positive returns (0.91\%) and low volatility $(1.09 \%)$. Bear currency carry markets persist, on average, for six months, whereas it is expected that bull currency carry markets persist for almost 20 months. Therefore, bull currency carry trade markets are estimated to be more persistent than bear currency carry trade markets and periods of expected increases in currency carry trade strategy returns with low volatility are disrupted by short periods of negative currency carry trade returns with much higher volatility. Figure 1 plots the filtered probability of bear currency carry markets. This probability is especially high in periods of financial uncertainty, such as the beginning of the 1990s, the Asian financial crisis in 1998 and clearly during the recent subprime crisis.

\footnotetext{
'The $L R$ test statistic, which tests the restriction that there is no relationship between currency carry trade returns and the market
} regimes extracted, gives a value larger than the $99 \%$ critical value and thus results in rejection. 
Table 1. Linear and Markov switching models of stock returns

\begin{tabular}{lll}
\hline & Linear & Markov switching \\
\hline$\mu$ & $0.44^{*}$ & $-0.81^{*}$ \\
\hline$\mu_{1}$ & & $0.91^{*}$ \\
\hline$\sigma_{2}^{2}$ & 3.61 & \\
\hline$\sigma_{1}^{2}$ & & $5.63^{\star}$ \\
\hline$\sigma_{2}^{2}$ & & $1.19^{\star}$ \\
\hline$P^{11}$ & & 0.95 \\
\hline$P^{22}$ & & 0.83 \\
\hline LogLik & -857 & -663 \\
\hline
\end{tabular}

This table reports the estimates of linear and Markov switching models of currency carry trade returns. The linear model is $r_{t}=\mu+\varepsilon_{t}$. The Markov switching model is $r_{t}=\mu_{s t}+\varepsilon_{t}$ with mean/variance $\left(\mu, \sigma_{1}^{2}\right)$ in regime 1 and $\left(\mu, \sigma_{2}^{2}\right)$ in regime 2 . * indicates significance at the $5 \%$ level.

\section{Figure 1. Filtered probabilities in state 1 (bear currency carry trade market)}

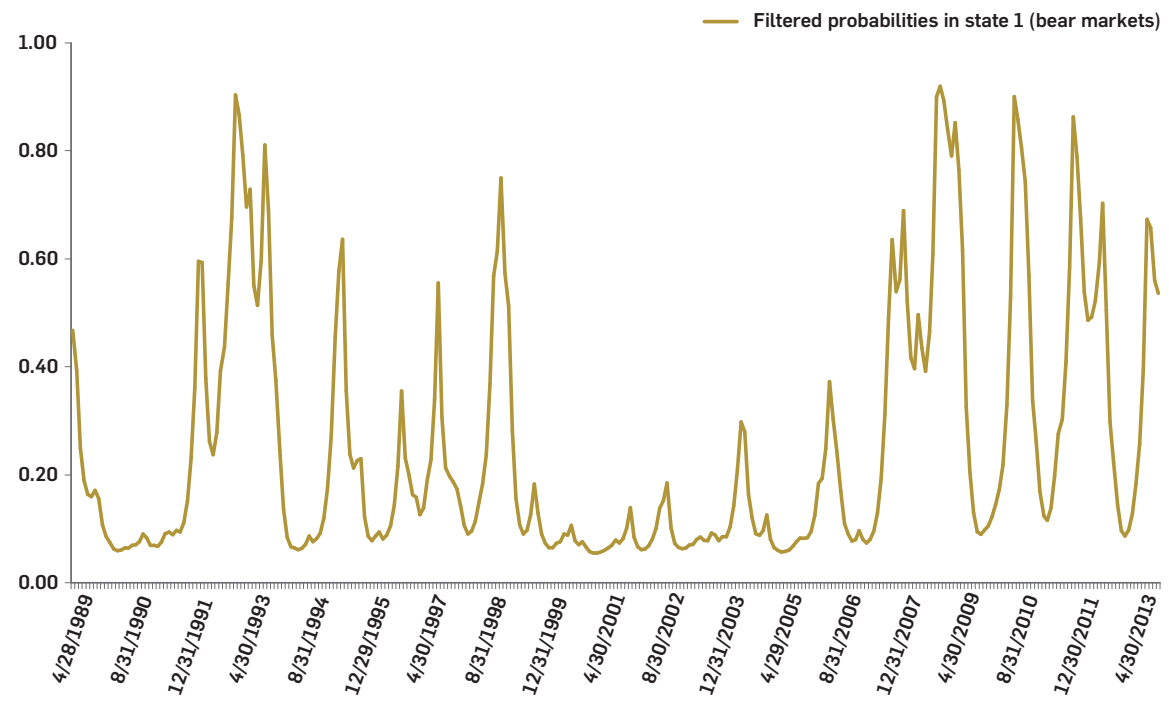

Table 2 shows the predictive power of the financial variables using linear models measured at different horizons (1, 3, 6, 12 and 24 months). According to $R^{2}$, the $F X$ volatility, the currency carry factor, the US TED spread and the three-month $C R B$ Industrial return have the best goodness-of-fit at horizons of one and three months. For longer horizons, up to 12 months, the US AFD delivers the highest $R^{2}$. None of the variables have significant predictive power using a horizon of 24 months. As expected, we find that all the variables, apart from the currency carry factor and the three-month $C R B$ Industrial return, have a positive relationship with the future filtered probability of bear currency carry markets. 
Table 2. In-sample predictability test results for predicting bear currency carry trade markets (Model 1: Markov switching model)

\begin{tabular}{|c|c|c|c|c|c|c|}
\hline & \multicolumn{3}{|c|}{ US TED spread } & \multicolumn{3}{|c|}{ FX volatility } \\
\hline & $\hat{\beta}$ & $p$-value & $R^{2}$ & $\hat{\beta}$ & p-value & $R^{2}$ \\
\hline$k=1$ & 0.23 & 0.00 & 0.13 & 0.04 & 0.00 & 0.29 \\
\hline$k=3$ & 0.22 & 0.00 & 0.11 & 0.03 & 0.00 & 0.18 \\
\hline$k=6$ & 0.16 & 0.00 & 0.08 & 0.01 & 0.01 & 0.03 \\
\hline$k=12$ & 0.04 & 0.31 & 0.00 & -0.001 & 0.98 & 0.00 \\
\hline \multirow{3}{*}{$k=24$} & 0.06 & 0.11 & 0.01 & 0.001 & 0.40 & 0.00 \\
\hline & \multicolumn{3}{|l|}{ US AFD } & \multicolumn{3}{|c|}{ Currency carry factor } \\
\hline & $\hat{\beta}$ & $p$-value & $R^{2}$ & $\hat{\beta}$ & p-value & $R^{2}$ \\
\hline$k=1$ & 0.03 & 0.00 & 0.06 & -0.03 & 0.00 & 0.08 \\
\hline$k=3$ & 0.03 & 0.00 & 0.07 & -0.03 & 0.00 & 0.10 \\
\hline$k=6$ & 0.03 & 0.00 & 0.07 & -0.01 & 0.04 & 0.02 \\
\hline$k=12$ & 0.02 & 0.00 & 0.05 & 0.01 & 0.30 & 0.00 \\
\hline \multirow[t]{3}{*}{$k=24$} & 0.001 & 0.25 & 0.00 & -0.01 & 0.29 & 0.00 \\
\hline & \multicolumn{3}{|c|}{ Three-month $C R B$ Industrial return } & \multicolumn{3}{|c|}{ Global currency skewness factor } \\
\hline & $\hat{\beta}$ & $p$-value & $R^{2}$ & $\hat{\beta}$ & p-value & $R^{2}$ \\
\hline$k=1$ & -0.01 & 0.00 & 0.08 & 0.03 & 0.11 & 0.01 \\
\hline$k=3$ & -0.01 & 0.00 & 0.06 & 0.03 & 0.13 & 0.10 \\
\hline$k=6$ & -0.00 & 0.43 & 0.00 & 0.03 & 0.17 & 0.02 \\
\hline$k=12$ & 0.00 & 0.35 & 0.01 & 0.00 & 0.84 & 0.00 \\
\hline \multirow[t]{3}{*}{$k=24$} & -0.01 & 0.03 & 0.01 & -0.02 & 0.47 & 0.00 \\
\hline & \multicolumn{3}{|l|}{$V I X$} & & & \\
\hline & $\hat{\beta}$ & $p$-value & $R^{2}$ & & & \\
\hline$k=1$ & 0.01 & 0.00 & 0.05 & & & \\
\hline$k=3$ & 0.01 & 0.00 & 0.03 & & & \\
\hline$k=6$ & -0.01 & 0.71 & 0.00 & & & \\
\hline$k=12$ & -0.01 & 0.03 & 0.02 & & & \\
\hline$k=24$ & -0.01 & 0.21 & 0.00 & & & \\
\hline
\end{tabular}

This table shows the results of the predictive regression model $P_{\text {Bear, } t+k}=\alpha+\beta x_{t}+\varepsilon_{t}$, where $P_{\text {Bear }, t+k}$ is the filtered probability obtained from the Markov switching model. Bold entries indicate significance at the $5 \%$ level.

Table 3 presents the chronology of the turning points of bear currency carry trade markets determined using the Bry-Boschan (1971) dating algorithm and the corresponding bull and bear currency carry trade periods. Bull markets (mean troughto-peak period 31 months) are generally longer than bear markets (mean peak-to-trough period nine months), reflecting that for most of the period studied, 
the currency carry trade was in a bull state. Interestingly, the Bry-Boschan (1971) dating algorithm estimates greater bull market persistence than the Markov switching estimation. The longest bull market period was between November 1998 and November 2005. The longest bear market period was between June 2007 and December 2008, corresponding to the initial phase of the subprime crisis that triggered huge losses from the naïve currency carry trade strategy. The mean currency carry trade percentage change during bear (bull) periods is $-16 \%(37 \%)$.

Table 3. Turning points of the currency carry trade market and corresponding bull and bear periods

\begin{tabular}{lccccc}
\hline Peaks & Troughs & $\begin{array}{c}\text { Bull duration } \\
\text { (months) }\end{array}$ & Bull change\% & $\begin{array}{c}\text { Bear duration } \\
\text { (months) }\end{array}$ & Bear Change \% \\
\hline $1992: 08$ & $1993: 07$ & & & 11 & $-28.05 \%$ \\
\hline $1994: 12$ & $1995: 06$ & 17 & $16.26 \%$ & 6 & $-11.25 \%$ \\
\hline $1998: 04$ & $1998: 11$ & 22 & $47.09 \%$ & 7 & $-7.05 \%$ \\
\hline $2005: 11$ & $2006: 06$ & 84 & $66.38 \%$ & 7 & $-9.09 \%$ \\
\hline $2007: 06$ & $2008: 12$ & 12 & $18.98 \%$ & 18 & $-25.64 \%$ \\
\hline $2013: 04$ & & 52 & $35.58 \%$ & & \\
\hline
\end{tabular}

The first (second) column gives the peak (through) turning points of the currency carry trade strategy described in section 3.2 determined by the Bry and Boschan (197I) dating method. Bull (bear) duration shows the time in month from the last trough (peak) to the next peak (trough). The percentage change of the currency carry trade strategy is denoted by "Change\%".

In Table 4, we present the probit regression results using the non-parametric Bry-Boschan (1971) dating algorithm. The pseudo $R^{2}$ values are relatively low and may uncover problems in the static probit models in relation to predicting bear and bull currency carry trade markets. The FX volatility, the currency carry factor and the US TED spread reach the highest goodness-of-fit at horizons of one and three months.

Table 4. In-sample predictability test results for predicting bear currency carry trade markets (Model 2: Bry-Boschan model)

\begin{tabular}{|c|c|c|c|c|c|c|}
\hline & \multicolumn{3}{|c|}{ US TED spread } & \multicolumn{3}{|c|}{ FX volatility } \\
\hline & $\hat{\beta}$ & $p$-value & Pseudo $R^{2}$ & $\hat{\beta}$ & $\mathrm{p}$-value & Pseudo $R^{2}$ \\
\hline$k=1$ & 1.53 & 0.00 & 0.14 & 0.07 & 0.00 & 0.03 \\
\hline$k=3$ & 0.99 & 0.00 & 0.08 & -0.02 & 0.63 & 0.00 \\
\hline$k=6$ & 0.59 & 0.01 & 0.03 & -0.06 & 0.05 & 0.01 \\
\hline$k=12$ & 0.11 & 0.61 & 0.00 & -0.16 & 0.00 & 0.06 \\
\hline$k=24$ & -0.49 & 0.12 & 0.01 & -0.04 & 0.20 & 0.00 \\
\hline
\end{tabular}




\begin{tabular}{|c|c|c|c|c|c|c|}
\hline & \multicolumn{3}{|l|}{ US AFD } & \multicolumn{3}{|c|}{ Currency carry factor } \\
\hline & $\hat{\beta}$ & $p$-value & Pseudo $R^{2}$ & $\hat{\beta}$ & $\mathrm{p}$-value & Pseudo $R^{2}$ \\
\hline$k=1$ & 0.05 & 0.24 & 0.01 & -0.20 & 0.00 & 0.13 \\
\hline$k=3$ & 0.03 & 0.31 & 0.00 & -0.06 & 0.03 & 0.02 \\
\hline$k=6$ & 0.03 & 0.42 & 0.001 & 0.01 & 0.87 & 0.00 \\
\hline$k=12$ & -0.02 & 0.52 & 0.00 & 0.04 & 0.23 & 0.01 \\
\hline \multirow[t]{3}{*}{$k=24$} & -0.02 & 0.69 & 0.00 & -0.03 & 0.38 & 0.00 \\
\hline & \multicolumn{3}{|c|}{ Three-month $C R B$ Industrial return } & \multicolumn{3}{|c|}{ Global currency skewness factor } \\
\hline & $\hat{\beta}$ & $p$-value & Pseudo $R^{2}$ & $\hat{\beta}$ & p-value & Pseudo $R^{2}$ \\
\hline$k=1$ & -0.01 & 0.17 & 0.00 & 0.12 & 0.41 & 0.00 \\
\hline$k=3$ & 0.01 & 0.44 & 0.00 & 0.05 & 0.39 & 0.00 \\
\hline$k=6$ & 0.01 & 0.26 & 0.01 & -0.01 & 0.93 & 0.00 \\
\hline$k=12$ & 0.02 & 0.15 & 0.01 & 0.06 & 0.65 & 0.00 \\
\hline \multirow[t]{3}{*}{$k=24$} & 0.00 & 0.78 & 0.00 & -0.01 & 0.96 & 0.00 \\
\hline & \multicolumn{3}{|l|}{$V I X$} & & & \\
\hline & $\hat{\beta}$ & $p$-value & Pseudo $R^{2}$ & & & \\
\hline$k=1$ & 0.00 & 0.93 & 0.00 & & & \\
\hline$k=3$ & -0.03 & 0.02 & 0.02 & & & \\
\hline$k=6$ & -0.05 & 0.00 & 0.06 & & & \\
\hline$k=12$ & -0.06 & 0.00 & 0.07 & & & \\
\hline$k=24$ & -0.06 & 0.00 & 0.08 & & & \\
\hline
\end{tabular}

This table shows the results of the predictive regression model $\operatorname{Pr}\left(D_{B e a r, t+k}=1\right)=F\left(\alpha+\beta x_{t}+\varepsilon_{t}\right)$, where $D_{\text {Bear, } t+k}$ is a dummy variable so that $D_{\text {Bear }, t+k}=1$ if in a bear currency carry market and $D_{\text {Bear }, t+k}=0$ if in a bull currency carry market. The bear currency carry trade market is identified using the Bry-Boschan method. Bold entries indicate significance at the $5 \%$ level.

\subsubsection{Out-of-sample results}

In this section, we report the out-of-sample results obtained by setting the out-ofsample period at 2002M1-2013M10. Forecasts are constructed using an expanded window of observations in which the data from the start of the dataset through to the present forecast time are used to obtain a new forecast. This process is repeated until the end of the sample. Table 5 shows that the out-of-sample test results using the nested models (7) and (8) display similar patterns to the in-sample results. For short horizons (one to six months), the $F X$ volatility, the currency carry factor, the US TED spread and the three-month $C R B$ Industrial return have predictive power for future bear currency carry trade probability, estimated using the Markov switching model, and Clark and West's (2007) MSPE-adjusted statistic rejects the equal forecasting accuracy. For longer horizons, most of the variables lack predictive ability, and Clark and West's (2007) MSPE-adjusted statistic does not reject the equal forecasting accuracy of both the restricted and the unrestricted models. 
Table 5. Out-of-sample predictability test results for predicting bear currency carry markets: Clark and West's (2007) MSPE-adjusted statistic (Model 1: Markov switching model)

\begin{tabular}{lccccr}
\hline & $k=1$ & $k=3$ & $k=6$ & $k=12$ & $k=24$ \\
\hline US TED spread & 2.66 & 2.55 & 1.79 & 0.85 & 0.75 \\
\hline FX volatility & 3.55 & 3.24 & 1.94 & 1.06 & 0.85 \\
\hline US AFD & 3.10 & 2.59 & 1.86 & -0.97 & -2.12 \\
\hline Currency carry factor & 1.59 & 2.41 & 1.34 & 0.10 & -0.75 \\
\hline Global currency skewness factor & -0.97 & -0.45 & -0.22 & -1.24 & -0.27 \\
\hline Three-month CRB Industrial return & 3.02 & 3.53 & 0.11 & 3.07 & 0.51 \\
\hline VIX & 1.57 & 1.43 & -0.41 & 2.51 & 0.80 \\
\hline
\end{tabular}

The critical values are $1.282(10 \%)$ and $1.645(5 \%)$. Bold entries indicate significance at the $10 \%$ level.The predictive regression model is $P_{\text {Bear } t+k}=\alpha+\beta x_{t}+\varepsilon_{t}$, where $P_{\text {Bear } t+k}$ is the filtered probability obtained from the Markov switching model.

The QPS score used to evaluate the out-of-sample predictive ability of financial variables concerning future bear currency carry trade probability, estimated using the Bry-Boschan (1971) algorithm, shows similar values across horizons and financial variables (see Table 6).

Table 6. Out-of-sample predictability test results for probit regression models: Diebold and Rudebusch's (1989) QPS (Model 2: Bry-Boschan method)

\begin{tabular}{llllll}
\hline & $k=1$ & $k=3$ & $k=6$ & $k=12$ & $k=24$ \\
\hline US TED spread & 0.27 & 0.27 & 0.31 & 0.34 & 0.34 \\
\hline FX volatility & 0.34 & 0.36 & 0.36 & 0.36 & 0.35 \\
\hline US AFD & 0.36 & 0.36 & 0.37 & 0.36 & 0.36 \\
\hline Currency carry factor & 0.34 & 0.36 & 0.37 & 0.37 & 0.36 \\
\hline Global currency skewness factor & 0.35 & 0.36 & 0.36 & 0.36 & 0.37 \\
\hline Three-month CRB Industrial return & 0.35 & 0.35 & 0.35 & 0.36 & 0.36 \\
\hline VIX & 0.36 & 0.35 & 0.31 & 0.29 & 0.30 \\
\hline
\end{tabular}

This table shows the results of the predictive regression model $\operatorname{Pr}\left(D_{B e a r t+k}=1\right)=F\left(\alpha+\beta x_{t}+\varepsilon_{t}\right)$, where $D_{B e a r t+k}$ is a dummy variable so that $D_{\text {Bear },+k}=1$ if in a bear currency carry market and $D_{\text {Bear }, t+k}=0$ if in a bull currency carry market.The bear market is identified using the Bry-Boschan method.The QPS ranges from 0 to 2 with a score of 0 corresponding to perfect accuracy.

\section{Economic implications of} predicting bear currency carry trade markets

Section 3.3.2. examined the evidence of the out-of-sample predictability of bear currency carry trade markets using parametric and non-parametric models that included financial variables as leading indicators, especially for the one- to six-month horizons. 
This section studies the economic value of the predictive power of the one-month bear currency carry trade market probability forecast within an asset allocation approach, assuming no transaction costs. We ask how predictability affects the optimal portfolio choice for investors with a monthly horizon and - more importantly - the economic value added to an expected utility maximizing investor who uses the bear currency carry trade market probability forecasts from parametric or non-parametric models relative to an investor who engages in the usual naïve currency carry trade activity.

We exploit the methodology developed by Brandt (1999), Ait-Sahalia and Brandt (2001) and Brandt et al. (2009) to obtain optimal currency carry trade strategies. This literature endeavours to draw inferences about optimal portfolio weights without explicitly modelling the underlying return distribution. The optimal allocation for each asset class can be expressed as a function of state variables considered by the investor.

In our setting, the advantage of this method over standard carry trade strategies lies in the possibility of switching between long and short positions in the carry trade portfolio depending on the values of the bear currency carry trade market probability forecast, $\hat{P}_{1, t+1}$. This variable is assumed to summarize the investor information set at time $t$. Our method also allows us to determine the optimal investor switching strategy without assuming a priori values of the estimated bear currency carry market probability forecast, which can be used mechanically to determine the investor strategy (Chen, 2009). We can also compare homogeneously the usefulness of considering the bear currency carry trade market probability forecast, defined by parametric versus non-parametric methods, within an asset allocation framework.

Our optimal portfolio is characterized at period $t$ by investing $100 \%$ of the investor's wealth in the US risk-free asset, yielding $r f_{t}^{U S}$, and the size bet to the naïve currency carry trade, $\alpha_{\text {Carry,t }}$. The return on this portfolio at $t+1$ can be expressed in terms of the naïve currency carry trade portfolio payoff, $R_{t+1, \text { Carry }}$, as:

$$
r_{p, t+1}=r f_{t}^{U S}+\alpha_{\text {Carry }, t} R_{t+1, \text { Carry }} .
$$

The optimality of this portfolio relies on the choice of the time-varying weight function, $\alpha_{\text {Carry,t }}$, that is determined by the investor at time $t$. A negative (positive) value of this weight implies a short (long) position on the naïve currency carry trade portfolio. Only when $\alpha_{\text {Carry }, t}=1$ is the usual naïve currency carry trade optimal. We follow Brandt et al. (2009) and model the optimal currency carry trade size bet, $\alpha_{\text {Carry,t }}$, directly as a function of the state variables, $Z_{t}$, that is:

$$
\alpha_{\text {Carry }, t}=\alpha\left(Z_{t} ; \beta\right)=Z_{t}^{\prime} \beta \text {, }
$$


where $\beta$ represents a vector of coefficients for optimal selection. In order to make these theoretical results operational, we assume that vector $Z_{t}$ is equal to the onemonth bear currency carry market probability forecast, $Z_{t}=\hat{P}_{1, t+1}$.

The investor's optimal allocation problem is to maximize expected utility conditional on the set of information available at time $t$. This problem is mathematically stated as:

$$
\underset{\beta}{\operatorname{Max}} E\left[U\left(r_{p, t+1}\left(\alpha\left(Z_{t} ; \beta\right)\right)\right) \mid Z_{t}\right]
$$

with $U\left(R_{p, t+1} ; \beta\right)$ denoting the investor's utility and $E\left(\cdot \mid Z_{t}\right)$ the mathematical expectation conditional on $Z_{t}$. The first order conditions of this maximization problem can be expressed as:

$$
E\left(U^{\prime}\left(r_{p, t+1}\left(\alpha\left(Z_{t} ; \beta\right)\right)\right) R_{t+1, \text { Carry }} \mid Z_{t}\right)=0
$$

with $U^{\prime}(\cdot)$ denoting the investor's marginal utility with respect to vector $\beta$. Brandt et al. (2009) show that the linear specification of the weight function implies that (15) is equivalent to the following equation obtained from the unconditional version of the optimization problem (14). In particular, the relevant system of equations is:

$$
E\left(U^{\prime}\left(r_{p, t+1}\left(\alpha\left(Z_{t} ; \beta\right)\right)\right) R_{t+1, c a r r y} \otimes z_{t}\right)=0
$$

where the symbol $\otimes$ represents Kronecker's product connoting element by element multiplication. The above representation of the optimal asset allocation problem yields a testable representation that can be implemented using generalized method of moments (GMM) techniques (Hansen, 1982).

The optimal currency carry trade size bet specification that depends on the bear currency carry trade market probability forecast is:

$$
\alpha_{\text {Carr }, t}=\alpha\left(Z_{t} ; \beta\right)=\beta_{0}+\beta_{1} \hat{P}_{1, t+1}
$$

We consider the investor's utility function to be isoelastic or CRRA and it takes the following form:

$$
U\left(r p_{t+1}\right)=\frac{\left(1+r p_{t+1}\right)^{1-\gamma}}{1-\gamma}
$$

with $\gamma$ the investor's constant relative risk aversion (CRRA) coefficient. If $\gamma=1$, the utility function is $U\left(r p_{t+1}\right)=\log \left(1+r p_{t+1}\right)$. The expected $C R R A$ utility not only depends on the first and second moments of the currency carry trade return distribution, but also on higher order moments, such as the skewness and kurtosis (Brandt et al., 2009). 
We use the following performance measures to measure the economic performance of bear currency carry trade market probability predictions: 1) the Sharpe ratio, calculated as the mean portfolio excess return divided by the portfolio return volatility, 2) the terminal wealth and 3 ) the difference in certainty equivalent returns (CERs), defined as the annualized difference between the CER calculated from the utility of the models that incorporate the estimated bear currency carry market probability and the CER corresponding to the utility using the naive currency carry trade strategy. The CER expresses the risk-free return such that the investor values this return equivalently to the expected utility of the return of the risky portfolio, $r_{p, t+1}$. Under $C R R A$ utility, the CER is computed as:

$$
C E R=\left((1-\gamma) T^{-1} \sum_{t=1}^{T} U\left(1+r p_{t+1}\right)\right)^{1 /(1-\gamma)}-1 \text {. }
$$

\subsection{Economic values of the predicted bear currency carry trade market probability}

Tables 7 and 8 present the investment performance of in-sample optimized strategies using different bear currency carry trade market probability forecasts. The in-sample estimates that relate the optimal currency carry trade bet size to the bear currency carry trade market probability forecast, and the economic value of each strategy described by the Sharpe ratio, the terminal wealth and the difference in CERs, are computed assuming an investor with power utility function and $\gamma=5$.

Table 7 presents the estimated models and the economic value of the bear currency carry trade market probability forecasts, characterized using the Markov switching model. As expected, the currency carry trade bet size depends negatively on the bear currency carry trade market probability forecast for all the financial variables. The US TED spread, the $F X$ volatility, the currency carry factor and the three-month $C R B$ industrial return coefficients are significant. Using the predictions of the bear currency carry trade market probability forecast from these variables, we find that the optimal investor portfolio delivers a higher Sharpe ratio, always above 0.85 , than the usual naïve currency carry trade strategy, reaching a value of 0.59 . The difference in certainty equivalent returns are also strikingly positive for the US TED spread (6.50\%), the FX volatility (9.08\%), the currency carry factor (11.50\%) and the three-month $C R B$ Industrial return (7.21\%). Finally, US $\$ 1$, considered at the beginning of the in-sample period, would yield terminal values much higher than the naïve currency carry trade strategy at the end of the in-sample period.

Table 8 presents the estimated models and the economic value of the bear currency carry trade market probability forecasts, characterized using the Bry-Boschan (1971) algorithm. We obtain qualitatively similar results: the coefficients linked to the US $T E D$ spread, the $F X$ volatility, the currency carry factor and the three-month $C R B$ Industrial return are again significant. The optimal investor portfolio using these 
variables also delivers a higher Sharpe ratio and terminal wealth than the usual naïve currency carry trade strategy. The differences in certainty equivalent returns are also very positive for the US TED spread (6.76\%), the $F X$ volatility $(5.85 \%)$, the currency carry factor (5.75\%) and the three-month $C R B$ Industrial return (8.78\%). Therefore, the information embedded in the bear currency carry trade market probability forecast adds value to the expected utility maximizing investor. It also transpires that the financial variables producing the best bear currency carry trade market probability forecast also add the greatest economic value when used for portfolio decisions.

Table 7. Simple linear portfolio policy. In-sample results (Model 1: Markov switching model)

\begin{tabular}{lcccccccc}
\hline & $\begin{array}{c}\text { Naïve } \\
\text { currency } \\
\text { carry } \\
\text { trade }\end{array}$ & $\begin{array}{l}\text { US TED } \\
\text { spread }\end{array}$ & $\begin{array}{c}\text { FX } \\
\text { volatility }\end{array}$ & US AFD & $\begin{array}{c}\text { Currency } \\
\text { carry } \\
\text { factor }\end{array}$ & $\begin{array}{c}\text { Global } \\
\text { currency } \\
\text { skewness } \\
\text { factor }\end{array}$ & $\begin{array}{c}\text { Three-month } \\
\text { CRB } \\
\text { Industrial } \\
\text { return }\end{array}$ & VIX \\
\hline$\beta_{\text {probabilityMS }}$ & & -5.80 & -3.09 & -5.08 & -5.24 & -4.00 & -11.38 & -1.84 \\
\hline$t$-stat & $(-2.37)$ & $(2.27)$ & $(-1.39)$ & $(-2.09)$ & $(-1.29)$ & $(2.80)$ & $(-0.59)$ \\
\hline$\mu$ & 5.44 & 17.58 & 17.38 & 8.15 & 15.48 & 7.49 & 18.53 & 8.04 \\
\hline Sharpe ratio & 0.59 & 0.89 & 1.11 & 0.67 & 1.21 & 0.48 & 0.92 & 0.74 \\
\hline Terminal wealth & 3.26 & 41.23 & 45.77 & 5.73 & 35.67 & 4.32 & 50.89 & 5.78 \\
\hline CER & & 6.50 & 9.08 & 0.97 & 11.5 & -4.39 & 7.21 & 1.70 \\
\hline
\end{tabular}

This table shows estimates of the optimal currency carry trade portfolio policy specified in equation 17 and optimized for a power utility function with different CRRA coefficients $(\gamma=5)$ using the estimated Markov switching model probability as the state variable. This probability is estimated using the following predictor variables: the USTED spread, the FX volatility, the USAFD, the return on the usual currency carry trade or currency carry factor, the currency carry skewness factor, the three-month CRB Industrial return and the $V I X$ index. CER is the difference in certainty equivalent returns, defined as the annualized difference between the CER calculated from the utility from the models that incorporate the bear currency carry market probability forecast and the CER corresponding to the utility using the naïve currency carry trade strategy. We use data from Bloomberg for the period April 1989 to October 2013.

Table 8. Simple linear portfolio policy. In-sample results (Model 2: Bry-Boschan model)

\begin{tabular}{lcccccccc}
\hline & $\begin{array}{c}\text { Naïve } \\
\text { currency } \\
\text { carry } \\
\text { trade }\end{array}$ & $\begin{array}{l}\text { US TED } \\
\text { spread }\end{array}$ & $\begin{array}{c}F X \\
\text { volatility }\end{array}$ & US AFD & $\begin{array}{c}\text { Currency } \\
\text { carry } \\
\text { factor }\end{array}$ & $\begin{array}{c}\text { Global } \\
\text { currency } \\
\text { skewness } \\
\text { factor }\end{array}$ & $\begin{array}{c}\text { Three-month } \\
\text { CRB } \\
\text { Industrial } \\
\text { return }\end{array}$ & VIX \\
\hline$\beta_{\text {probabilityMS }}$ & & -2.93 & -6.61 & -13.13 & -2.79 & -5.08 & -30.42 & 6.89 \\
\hline$t$-stat & $(-2.5)$ & $(-2.21)$ & $(-1.39)$ & $(-2.15)$ & $(.14)$ & $(-2.76)$ & $(0.56)$ \\
\hline$\mu$ & 5.44 & 13.44 & 11.33 & 7.26 & 11.14 & 5.96 & 17.90 & 6.69 \\
\hline Sharpe ratio & 0.59 & 0.81 & 0.78 & 0.67 & 0.77 & 0.38 & 0.90 & 0.60 \\
\hline Terminal wealth & 3.26 & 17.27 & 11.28 & 9.54 & 10.82 & 2.91 & 37.91 & 4.19 \\
\hline CER & 6.76 & 5.85 & -1.36 & 5.75 & -7.78 & 8.78 & 3.41 & \\
\hline
\end{tabular}

This table shows estimates of the optimal currency carry trade portfolio policy specified in equation 17 and optimized for a power utility function with different CRRA coefficients $(\gamma=5)$ using the estimated Markov switching model probability as the state variable. This probability is estimated using the following predictor variables: the USTED spread, the FX volatility, the US AFD, the return on the usual currency carry trade or currency carry factor, the currency carry skewness factor, the three-month CRB Industrial return and the VIX index. CER is the difference in certainty equivalent returns, defined as the annualized difference between the CER calculated based on the utility from the models that incorporate the bear currency carry market probability forecast and the CER corresponding to the utility using the naive currency carry trade strategy. We use data from Bloomberg for the period April 1989 to October 2013. 
A simple comparison of the results from the parametric and non-parametric models used to characterize the bear market seems slightly to favour the predictions of bear currency carry trade market probability using parametric models. The information extracted from parametric models usually allows the investor to earn a higher Sharpe ratio, terminal wealth and certainty equivalent than the information extracted from the non-parametric models.

We also present an out-of-sample experiment to provide robustness to our results by setting the out-of-sample period to be 2002M1-2013M10. We use data from 1989M4-2001M12 to estimate the first optimal parametric portfolio. The model is then re-estimated for every year using an expanding window of data until the end of the sample. The investor uses the estimates at period $t$ to form the optimal currency carry trade between $t$ and $t+1$, given the one month out-of-sample bear currency carry trade market probability forecast obtained at time $t$, as discussed in 3.3.2. The outof-sample period covers periods of financial market instability, such as the plunge in the stock market valuations during 2002 and especially the subprime crisis that had extremely adverse effects on naïve currency carry trade profitability.

Tables 9 and 10 show the performance of the out-of-sample strategy. The results are qualitatively similar to the in-sample results with a sensible deterioration. In terms of the economic value of the bear currency carry trade market probability forecast, investors who consider the estimates from the US TED spread and the three-month $C R B$ Industrial return, and to a lesser extent from the $F X$ volatility and the currency carry factor, would be better off than those who engage in the naïve currency carry trade. Using the bear currency carry trade market probability forecast from these financial variables, within the asset allocation decision, investors achieve a higher Sharpe ratio and terminal wealth than from the naïve currency carry trade and also a positive difference in certainty equivalent.

Table 9. Simple linear portfolio policy. Out-of-sample results (Model 1: Markov switching model)

\begin{tabular}{lcccccccc}
\hline & $\begin{array}{c}\text { Naïve } \\
\text { currency } \\
\text { carry } \\
\text { trade }\end{array}$ & $\begin{array}{c}\text { US TED } \\
\text { spread }\end{array}$ & $\begin{array}{c}\text { FX } \\
\text { volatility }\end{array}$ & US AFD & $\begin{array}{c}\text { Currency } \\
\text { carry } \\
\text { factor }\end{array}$ & $\begin{array}{c}\text { Global } \\
\text { currency } \\
\text { skewness } \\
\text { factor }\end{array}$ & $\begin{array}{c}\text { Three-month } \\
\text { CRB } \\
\text { Industrial } \\
\text { return }\end{array}$ & VIX \\
\hline$\mu$ & 4.95 & 11.30 & 5.84 & 5.20 & 9.53 & 5.63 & 10.62 & 3.01 \\
\hline Sharpe ratio & 0.50 & 0.74 & 0.53 & 0.49 & 0.58 & 0.44 & 0.75 & 0.44 \\
\hline Terminal wealth & 1.67 & 3.39 & 1.82 & 1.71 & 2.57 & 1.74 & 3.04 & 1.38 \\
\hline CER & & $4.45 \%$ & $0.35 \%$ & $-0.24 \%$ & $1.34 \%$ & $-2.34 \%$ & $3.06 \%$ & $-0.56 \%$ \\
\hline
\end{tabular}

This table shows the economic value of the out-of-sample optimal currency carry trade portfolio policy specified in equation 17 and optimized for a power utility function with a CRRA coefficient $(\gamma=5)$ using the out-of-sample Markov switching model probability obtained in section 3.3.2 as the state variable. This probability is estimated using the following predictor variables: the US TED spread, the FX volatility, the US AFD, the return on the usual currency carry trade or currency carry factor, the currency carry skewness factor, 
the three-month CRB Industrial return and the VIX index. CER is the difference in certainty equivalent returns, defined as the annualized difference between the CER calculated based on the utility from the models that incorporate the bear currency carry market probability forecast and the CER corresponding to the utility using the naive currency carry trade strategy. We use data from Bloomberg for the period April 1989 to October 2013. Constants are omitted. We use data from I989M4-200 IMI 2 to estimate the first optimal parametric portfolio. The model is then re-estimated for every year using an expanding window of data until the end of the sample. The investor uses the estimates at period $t$ to form the optimal currency carry trade between $t$ and $t+1$, given the one-month out-of-sample bear currency carry trade probability forecast obtained in section 3.3 .2 at time $t$.

Table 10. Simple linear portfolio policy. Out-of-sample results

(Model 2: Bry-Boschan Model)

\begin{tabular}{lcccccccc}
\hline & $\begin{array}{c}\text { Naïve } \\
\text { currency } \\
\text { carry } \\
\text { trade }\end{array}$ & $\begin{array}{l}\text { US TED } \\
\text { spread }\end{array}$ & $\begin{array}{c}\text { FX } \\
\text { volatility }\end{array}$ & US AFD & $\begin{array}{c}\text { Currency } \\
\text { carry } \\
\text { factor }\end{array}$ & $\begin{array}{c}\text { Global } \\
\text { currency } \\
\text { skewness } \\
\text { factor }\end{array}$ & $\begin{array}{c}\text { Three-month } \\
\text { CRB } \\
\text { Industrial } \\
\text { return }\end{array}$ & VIX \\
\hline$\mu$ & 4.95 & 10.05 & 13.22 & 7.26 & 9.14 & 4.59 & 9.26 & 3.19 \\
\hline Sharpe ratio & 0.50 & 0.77 & 0.45 & 0.65 & 0.60 & 0.53 & 0.53 & 0.46 \\
\hline Terminal wealth & 1.67 & 2.91 & 2.70 & 2.85 & 2.52 & 1.63 & 2.40 & 1.45 \\
\hline CER & & $4.06 \%$ & $-5.35 \%$ & $1.78 \%$ & $0.94 \%$ & $0.25 \%$ & $1.56 \%$ & $-0.36 \%$ \\
\hline
\end{tabular}

This table shows the economic value of the out-of-sample optimal currency carry trade portfolio policy specified in equation 17 and optimized for a power utility function with a CRRA coefficient $(\gamma=5)$ using the out-of-sample Markov switching model probability obtained in section 3.3.2 as the state variable. This probability is estimated using the following predictor variables: the USTED spread, the FX volatility, the US AFD, the return on the usual currency carry trade or currency carry factor, the currency carry skewness factor, the three-month CRB Industrial return and the VIX index. CER is the difference in certainty equivalent returns, defined as the annualized difference between the CER calculated based on the utility from the models that incorporate the bear currency carry market probability forecast and the CER corresponding to the utility using the naive currency carry trade strategy. We use data from Bloomberg for the period April 1989 to October 2013. Constants are omitted. We use data from 1989M4-200 IMI 2 to estimate the first optimal parametric portfolio.The model is then re-estimated for every year using an expanding window of data until the end of the sample. The investor uses the estimates at period $t$ to form the optimal currency carry trade between $t$ and $t+1$, given the one-month out-of-sample bear currency carry trade probability forecast obtained in section 3.3.2 at time $t$.

Hence, the periods of deterioration in funding liquidity and worsening of the economic outlook, mirrored by increases in the US TED spread and by a plunge in commodity prices, have an upward effect on the bear currency carry market probability, giving the right signal of lowering the currency carry market bet size. Interestingly, the failure of the UIP appears to be linked to periods of high risk-taking behaviour and ample liquidity.

\section{Conclusion}

This paper investigates the predictive power of financial variables to anticipate bear currency carry trade markets, characterized using parametric and non-parametric methods, and also studies the economic value of the one-month bear currency carry trade market probability forecast in forming optimal investor portfolios. We find that the FX volatility, the currency carry factor, the US TED spread and the threemonth $C R B$ Industrial return have in-sample and out-of-sample predictive power in relation to future bear currency carry trade probability, especially for short horizons. The one-month bear currency carry trade market probability forecast from these variables also adds remarkable economic value to the investor compared to the naïve currency carry trade in terms of the Sharpe ratio, the terminal wealth and 
the certainty equivalent. As expected, we also find that the optimal currency carry trade bet size depends negatively on the bear currency carry trade market probability forecast.

\section{References}

Ait-Sahalia, Y. and Brandt, M. (2001). Variable selection for portfolio choice, Journal of Finance, 56, pp. 1297-1351.

Ang, A. and Timmermann, A. (2011). Regime changes and financial markets, NBER working paper, No. 17182.

Bakshi, G. and Panayotov, G. (2013). Predictability of currency carry trades and asset pricing implications, Journal of Financial Economics, 110(1), pp. 139-163. Available at http://www.sciencedirect.com/science/article/pii/ S0304405X13001347

Barroso, P. and Santa Clara, P. (2012). Beyond the carry trade: Optimal currency Portfolios, Unpublished working paper, NOVA School of Business and Economics. Available at http://www.oxford-man.ox.ac.uk/sites/default/ files/events/BeyondCarryTrade.pdf $\square$

Brandt, M. (1999). Estimating portfolio and consumption choice: a conditional method of moments approach, Journal of Finance, 54, pp. 1609-1646.

Brandt, M., Santa Clara, P. and Valkanov, R. (2009). Parametric portfolio policies exploiting the characteristics in the cross section of equity returns, Review of Financial Studies, 22, pp. 3411-3447.

Brunnermeier, M., Nagel, S. and Pedersen, L. (2008). Carry trades and currency crashes, NBER Macroeconomics Annual, 23, pp. 313-347.

Bry, G. and Boschan, C. (1971). Cyclical analysis of time series: selected procedures and computer programs, Technical Paper 20, NBER, Columbia University Press.

Burnside, C. (2012). Carry trades and risk, in: J. James, I. W. Marsh and L. Sarno (eds.), Handbook of Exchange Rates. Hoboken, John Wiley \& Sons, pp. 283-312.

Candelon, B., Piplack, J. and Straetmans, S. (2008). On measuring synchronization of bulls and bears: the case of East Asia, Journal of Banking and Finance, 32, pp. 1022-1035.

Chen, S. (2009). Predicting the bear stock market: macroeconomic variables as leading indicators, Journal of Banking and Finance, 33, pp. 211-233.

Chen, Y. and Rogoff, K. (2003). Commodity currencies, Journal of International Economics, 60 (1), pp. 133-160.

Christiansen, C., Ranaldo, A. and Soderlind, P. (2010). The time varying systematic risk of carry trade strategies, Journal of Financial and Quantitative Analysis, 46 (4), pp. 1107-1125.

Clark, T. and West, K. (2007). Approximate normal tests for equal predictive accuracy in nested models, Journal of Econometrics, 138 (1), pp. 291-311.

Diebold, F. and Rudesbuch, G. (1989). Scoring the leading indicators, Journal of Business, 62(3), pp. 369-391.

Estrella, A. (1998). Predicting U.S. recessions: financial variables as leading indicators, Review of Economic and Statistics, 16(2), pp. 198-205.

Fama, E. (1984). Forward and spot exchange rates, Journal of Monetary Economics, 19, pp. 319-338. 
Fama, E. and French, K. (1993). Common risk factors in the returns on stock and bonds, Journal of Financial Economics, 33, pp. 3-56.

Hamilton, J. (1989). A new approach to the economic analysis of nonstationary time series and the business cycle, Econometrica, 57, pp. 357-384.

Hansen, L. (1982). Large sample properties of generalized method of moments estimators, Econometrica, 50, pp. 1029-1054.

Lustig H. and Verdelhan, A. (2007). The cross-section of foreign currency risk premia and U.S. consumption growth risk, American Economic Review, 97(1), pp. 89-117.

Lustig, H., Roussanov, N. and Verdelhan, A. (2011). Common risk factors in currency markets, Review of Financial Studies, 24, pp. 3731-3777.

Lustig, H., Roussanov, N. and Verdelhan, A. (2013). Countercyclical currency risk premia, Journal of Financial Economics, forthcoming.

Menkhoff, L., Sarno, L., Schmeling, M. and Schrimpf, A. (2012). Carry trades and global foreign exchange volatility, Journal of Finance, 67(2), pp. 681-718.

Rafferty, B. (2011). Currency returns, skewness and crash risk, Working Paper, Duke University. Available at http://econ.duke.edu/uploads/media_items/barry-rafferty-job-market-paper.original.pdf $\square$ 
